\title{
Can Real Property Law Play a Role in Addressing Housing Vulnerability? The Case of Older Women Experiencing Housing Stress and Homelessness
}

\author{
Ben Travia and Eileen Webb
}

\begin{abstract}
There is much discussion about the shortage of affordable housing in Australia and the rising tide of homelessness. Perhaps surprisingly to some, older women are one of the fastest growing groups of people experiencing homelessness. In the aftermath of a lifetime of income inequality and taking 'time out' for caring responsibilities, older women may be in a precarious position should they encounter illness, divorce or unemployment in mid to older age. This article outlines the background to the growing number of older women experiencing homelessness and, although the authors are not suggesting the law can provide 'the answer' to this multi-faceted conundrum, the article examines possible contributions the law could make in alleviating some pitfalls encountered by older women experiencing housing stress or homelessness.
\end{abstract}

\begin{abstract}
I know women approaching retirement age facing subsistence living in the midst of our affluent society. Foregoing education in the 1960s because of cost and the expectation to marry, they devoted themselves to raising children, doing voluntary work and supporting their husbands' career advancement. Through widowhood or divorce, they have ended up living alone. The paid work they have since undertaken has been largely unskilled in retail or service industries. Employers had offered only casual work, varying greatly in hours from week to week and affecting their financial independence. ${ }^{1}$
\end{abstract}

An increasing number of women at or nearing retirement age are unable to access affordable and secure housing. ${ }^{2}$ The problem is not unique to Australia; the number of women who teeter on the brink of homelessness,

$1 \quad$ K Galloway, 'Ending feminised poverty', Eureka Street, 10 September 2014: $<$ http://www.eurekastreet.com.au/article.aspx?aeid=41973\#.VQ_oco7Ld-M>.

2 Although there is no doubt that the circumstances of older homeless women are worsening in most developed economies, there has been little research on the issue. Indeed, Australia is one of the few countries affected that is pursuing a comprehensive research agenda on older homeless women: Maree Peterson and Cameron Parsell, Older Women's Pathways out of Homelessness in Australia (Report for the Mercy Foundation, Institute for Social Science Research The University of Queensland Australia, February 2014) 2, <https://www.mercyfoundation.com.au/_uploads/_cknw/files/FINAL\%20Feb\%202014\%20Petersen\%20 \%20Parsell\%20Older\%20women $\% 27 \mathrm{~s} \% 20$ pathways $\% 20$ out $\% 20$ of $\% 20$ homelessness.pdf>. 
or actually become homeless (often for the first time) in middle to older age $^{3}$ has been increasing in most developed economies. While far from a homogenous group in terms of demography, older homeless women rarely correspond to society's ubiquitous image of the homeless. Sadly, when many people think of an older homeless woman the mind's eye often defaults to the 'stereotype of the bag lady sheltering in a bus station'. ${ }^{4}$ While some homeless women have experienced many years of 'living rough' or a life punctuated by periods of homelessness necessitated by crisis, ${ }^{5}$ many find themselves homeless for the first time in their lives in middle or older age. Indeed, the recent Older Women's Pathways out of Homelessness in Australia Report notes:

The largest proportion of older women presenting with housing crisis in Australia have led conventional lives, and rented whilst working and raising a family. Few have had involvement with welfare and support systems. ${ }^{6}$

Also, older women are less likely than their male counterparts to acknowledge that they are experiencing housing stress or are, in fact, homeless. ${ }^{7}$ To many of these women, being in such a situation is a source of considerable embarrassment and gives rise to feelings of inadequacy and failure. ${ }^{8}$ Older homeless women tend to be more resourceful with finding temporary accommodation through, for example, 'couch-surfing' and do not access homelessness services at an equivalent extent to other groups. ${ }^{9}$ The resultant 'invisibility' of these women means that it difficult to assess accurately the true extent of the issue and identify women who are experiencing homelessness. ${ }^{10}$

$3 \quad$ For ease of reference we will refer to these women as 'older homeless women' collectively. Indeed, it is common for some women to drift between circumstances of housing vulnerability and actual homelessness. Where we are referring to one circumstance or the other we will emphasise.

4 Anne J Kisor and Lynne Kendal-Wilson, 'Older Homeless Women: Reframing the Stereotype of the Bag Lady' (2002) 17 Affila 354; M Sullivan, 'The Homeless Older Woman in Context: Alienation, Cutoff and Reconnection' (1991) 3(2) Journal of Women and Aging 3.

$5 \quad$ For example, through domestic violence: Felicity Reynolds, CEO Mercy Foundation - Older Women and Homelessness (Presentation to Australasian Housing Institute NSW, August 2014) <http://www.cotansw.com.au/MediaPDFs/ Felicity-Reynolds-parliamentary-forum-presentation.pdf $>$.

6 Peterson and Parsell, above n 2. See also Chris Chamberlain and Guy Johnson, 'Pathways into Adult Homelessness' (2013) 49 Journal of Sociology 60.

7 Peterson and Parsell, above n 2.

8 ACT Shelter Inc, 'Home Truths: Older women's housing vulnerability in the ACT' (Announcement, August 2014) <http://www.actshelter.net.au/announcements/ home-truths-older-womens-housing-vulnerability-in-the-act-1>.

9 Lisa Brunette, For Homeless Women, an Alternative to Couch Surfing (2007), $<$ http://crosscut.com/2007/10/for-homeless-women-alternative-couchsurfing/>; Reynolds, above n 5 , notes the 'increase in older women staying temporarily with others or in overcrowded housing increased by $17 \%$ '.

10 Peterson and Parsell, above n 2, 2-3. At p 26 the authors refer to Sandy Darab, Yvonne Hartman, 'Understanding single older women's invisibility in housing issues in Australia' (2013) 30(4) Housing, Theory and Society 348 and state: '[W]omen's traditional roles in society, reluctance to seek assistance and the 
This article considers (the lack of) legal security of tenure ${ }^{11}$ that, for many older women, will lead to homelessness. Housing vulnerability and homelessness can be viewed from several perspectives: a welfare issue; a poverty issue; a product of institutional or market failure; or a dereliction of personal responsibility. More recently, it has been considered a property, or in some cases a 'no property' issue. ${ }^{12}$ It is acknowledged that many legal issues impact on older homeless women and it is artificial to limit a discussion of those issues to legal security of tenure, a concept seen as rooted in real property law. However, lack of tenure is the foundation of homelessness; finding ways to fortify security of tenure is a contribution lawyers are well equipped to make.

The objective of this article is to consider whether real property law can play a meaningful role in addressing housing vulnerability in Australia and uses the case of older woman experiencing housing stress and homelessness as an illustration. Homelessness 'law' tends to be dominated by issues involving inter alia, social security, credit and debt and the criminal law. ${ }^{13}$ Real property law is rarely considered in legal discourse about homelessness, ${ }^{14}$ and any such discussions focus on the consequences of the lack of property rights rather than exploring the possibility of better utilising property law to forestall housing vulnerability and homelessness. ${ }^{15}$ Legislation such as the State and Territory residential tenancy acts seek to balance the rights of landlords and tenants but, in fact, do little to enhance security of tenure; such legislation does little to prevent significant rental increases, does not impose minimum standards on rental properties and permits 'no cause' termination of tenancies. ${ }^{16}$

existing service provision environment have been shaped by neoliberal ideologies - and are factors that have contributed to the invisibility of women facing housing stress and homelessness'.

11 At this stage it is instructive to contrast 'legal' security of tenure with ontological security. References to legal security of tenure focus on the legal right to remain in accommodation for a designated period whereas ontological security focuses on notions of 'home' (constancy of their social and material environments) rather than legal tenure: Anthony Giddens, Modernity and Self Identity: Self and Society in the Late Modern Age (Polity Press, 1991); Ann Dupuis and David C Thorns, 'Home, Home Ownership and the Search for Ontological Security' (1998) 46 Sociological Review 24. Although ontological security is of considerable importance for those in marginal housing circumstances, this article's focus is on the substance and effectiveness of existing laws.

12 Jane B Baron, 'Homelessness as a Property Problem' (2004) 36 Urban Lawyer 273; Jane B Baron, 'Review: The "No Property" Problem: Understanding poverty by understanding wealth' (2004) 102 Michigan Law Review 1000.

13 The law often becomes involved after a person becomes homeless as the circumstances of being homeless, for example, the need to occupy public spaces, may attract the attention of the criminal law. For example, in the Western Australian research some older women who were living in cars reported being 'moved on' from carparks by police or rangers.

14 Dupuis and Thorns, above n 11, 25.

15 Ibid.

16 Residential Tenancies Act 1997 (ACT); Residential Tenancies Act 2010 (NSW); Residential Tenancies Act (NT); Residential Tenancies Act 1994 (Qld); Residential 
Similar assessments are applicable to State and Territory legislation involving other forms of accommodation including manufactured home parks, caravan parks and boarding houses.

The authors are not under any illusions that property law can 'fix' the homelessness issue. The article suggests, however, that there is potential to use existing international obligations in relation to housing, and in appropriate circumstances, women and the ageing to inform the interpretation of existing law and provide the basis for law reform.

Part 1 of the article provides background to the ensuing discussions by outlining the scale of, and reasons for, the growth in the numbers of older people, in particular women, who are experiencing housing stress or are homeless. It also considers factors impacting on the Australian housing market of relevance to older people. Part 2 discusses findings from recent research that considered the security of tenure of older Western Australians. The research included a focus on older people in marginal accommodation and noted a marked increase in the number of older women experiencing housing vulnerability in older age. The findings concluded inter alia that the circumstances and the responses of older women experiencing housing vulnerability often differed from those of older men in the same predicament. ${ }^{17}$ Part 3 notes that the law impacts upon homeless people in a variety of ways, in particular the criminal law through being required to 'move on' from public places. The problem is, however, that the law is used after a person becomes homeless and often serves to compound a homeless person's predicament. The article then considers what the law could do before a person becomes homeless, in particular to maintain and protect existing tenancies. It considers whether property law, particularly landlord and tenant law, could - or should - play a role in supporting accommodation arrangements for people in vulnerable housing circumstances. In so doing, Part 8 also considers Australia's international obligations and domestic laws in relation to adequate housing, women and the ageing and makes suggestions for relevant law reform. ${ }^{18}$ Again, the discussion will be illustrated by reference to older women. ${ }^{19}$ The article concludes with a summary of recommendations.

Tenancies Act 1995 (SA); Residential Tenancies Act 1997 (Tas); Residential Tenancies Act 1997 (Vic); Residential Tenancies Act 1987 (WA).

17 Aviva Freilich et al, Security of tenure for the ageing population in Western Australia - Does current housing legislation support seniors' ongoing housing needs? (November 2014) <http://www.cotawa.org.au/wp-content/ uploads/2015/04/121975_Housing-Report-text.pdf $>$. In the course of this article this report will be referred to as the Western Australian Research.

18 In so doing, the article ponders the seeming absence of discussions about real property law in considerations of homelessness and law: Nicholas Blomley, 'Homelessness, rights, and the delusions of property' (2009) 30 Urban Geography 577, 577-578; see also Baron, 'Homelessness as a Property Problem', above $\mathrm{n} 12$.

19 Although some issues are common to homeless people of all ages, some will affect older women in particular ways. 


\section{Housing Vulnerability and Homelessness Affecting Older Australians}

\section{A Perceptions of Older People and Home}

Decades of relative prosperity since the end of the Second World War have seen the 'baby boomers' emerge as the most affluent generation in recent history. ${ }^{20}$ Much of this wealth was obtained through ownership of real property and a consistent growth in property values.

It is often assumed that older people are comfortable in their own home and enjoy considerable security of tenure. What is often overlooked is the plight of the 'boomers' who did not, or could not, take advantage of the prosperous times. It can be forgotten too that due to the vagaries of life - for example illness, unemployment, divorce or minimal superannuation - many people lack resources in older age.

The reality is that many older people live in marginal accommodation. In recent times, many older long term renters have been priced out of inner city properties and moved out of familiar neighbourhoods. ${ }^{21}$ There is a shortage of social housing across Australia such that older renters in the private market may have to wait several years for public housing to become available. Even those people who have owned their own home may find that their housing situation can become precarious: family accommodation (assets for care) arrangements with children may break down, retirement village or aged care arrangements may be unsuccessful, or those who have invested in manufactured homes may see the park land sold for redevelopment. ${ }^{22}$ There is no age limit on domestic violence and homelessness may be the result of physical, mental and/or financial abuse.

It is difficult for society to acknowledge that older people, particularly women, are in such a predicament. ${ }^{23}$ There is a tendency to view older people through society's ideal of loved and loving senior citizens. ${ }^{24}$ Financial and housing insecurity in older age is often viewed with suspicion and met with the insinuation that a person has not been careful with

20 Households in the 65-74 age group have the highest mean net value of owner occupied property at $\$ 448,100$ and for all property at $\$ 572,500$. Households in the baby boomer age groups of 45-54 and 55-64 years also have relatively high net wealth in housing assets; SGS Economics and Planning, Baby Boomers, Planning and Productivity-Discussing ABS, Household Wealth and Wealth Distribution 2009-2010 (14 October 2011), <http://www.sgsep.com.au/insights/ urbecon/baby-boomers-housing-and-productivity/>.

21 Freilich, above $\mathrm{n} 17$.

22 Ibid.

23 Peter Rossi, 'The old homeless and the new homelessness in historical perspective' (1990) 45(8) American Psychologist 954.

24 Jennifer Richeson and J Nicole Shelton, 'A Social Psychological Perspective on the Stigmatization of Older Adult - When I'm 64' 2006 National Research Council (US) Committee on Aging Frontiers in Social Psychology, Personality, and Adult Developmental Psychology (2006); LL Carstensen, CR Hartel (eds), Washington (DC): National Academies Press (US) < http://www.ncbi.nlm.nih.gov/ books/NBK83758/>. 
their finances or there is some other 'fault' on that person's part. ${ }^{25}$ Also, in these circumstances many older people feel shame that they cannot 'support' themselves adequately and are reluctant to seek assistance. ${ }^{26}$

\section{B Defining and Quantifying Homelessness}

1 The Elusiveness of a Definition

According to the Australian Bureau of Statistics, a person is homeless if they do not have suitable accommodation alternatives and their current living arrangement:

- is in a dwelling that is inadequate; or

- has no tenure, or if their initial tenure is short and not extendable; or

- does not allow them to have control of, and access to space for social relations. ${ }^{27}$

Differing types of 'homelessness' are often divided into gradients;

1. primary; for example sleeping rough;

2. secondary; staying with friends/relatives and with no fixed address, or people residing in specialist homelessness services; and

3. tertiary; including those living in boarding houses or caravan parks with no secure lease and no private facilities, both short and long-term. ${ }^{28}$

Perhaps surprisingly, there is no uniform definition of 'homeless'. ${ }^{29} \mathrm{~A}$ definition provided by Chris Chamberlain and David Mackenzie ${ }^{30}$ held sway for a considerable time and forms the basis - with some recent amendments to widen the definition's scope - of the ABS definition. ${ }^{31}$

25 This is a common perception. In a broader context, Burbank refers to this tendency as a 'social judgement' that 'is analogous to the concepts of moral evaluation, social evaluation and labelling'. Patricia Burbank, Vulnerable Older Adults: Health Care Needs and Interventions (Springer Publishing Company Inc New York, 2006) 142.

26 Stephen Parker, Rodney Fopp, "I'm the Slice of Pie that's Ostracised ...". Foucault's Technologies, and Personal Agency, in the Voice of Women who are Homeless, Adelaide, South Australia' (2004) 21 Housing, Theory and Society 145, 147; Jeff Fiedler, 'Better Services and Housing Outcomes: A New Lease on Life for Older People 2011' (2011) 24 Parity 19, 19-21.

27 Australian Bureau of Statistics, ABS Information Paper: A Statistical Definition of Homelessness (2012), <http://www.ausstats.abs.gov.au/Ausstats/subscriber. nsf/0/B4B1A5BC17CEDBC9CA257A6E00186823/\$File/49220_2012.pdf>.

28 Chris Chamberlain and David MacKenzie, 'Understanding Contemporary Homelessness: Issues of Definition and Meaning' (1992) 27 Australian Journal of Social Issues 4, 274.

29 The issue of a definition was also the subject of debate during drafting of the Homelessness Bill 2013 (Cth).This proposed legislation is discussed in the course of this article.

30 Chamberlain and MacKenzie, above n 28.

31 Tamara Walsh, 'Homelessness Legislation for Australia: A Missed Opportunity' (2014) 37 University of New South Wales Law Journal 820, 827. 
This definition has, however, been criticised by advocates for its emphasis on housing standards rather than 'the homeless experience' ${ }^{32}$ including 'lack of safety and social inclusion'. ${ }^{33}$ FaHCSIA emphasises that 'homeless' includes not only those that are sleeping rough outdoors, but also people staying in improvised dwellings, tents or sleeping out; supported accommodation for the homeless; temporary arrangements with other households; substandard boarding houses; temporary lodgings; and 'severely' overcrowded dwellings. ${ }^{34}$

This broad meaning reflects the fact that many people, including seniors, reside in marginal forms of accommodation and, while many are primarily homeless, or have been homeless for a lengthy period, others may move in and out of homelessness. It is important to recognise that homelessness is a state with connotations beyond simply 'being without shelter'. It impacts upon all areas of a person's life; from employment, security and health to family and social engagement..$^{35}$

\section{Rates of Homelessness}

Homelessness amongst older Australians has been increasing. ${ }^{36}$ In 2013, there was a 14 per cent increase in the number of Australians aged over 55 who sought assistance from specialist homelessness agencies in the previous year. ${ }^{37}$ Women now make up 36 per cent of homeless older people and numbers are increasing ${ }^{38}$ with the number of homeless women over 55 increasing by 12 per cent between 2006 and $2011 .^{39}$

Clearly, such statistics are inexact and it is likely the figures are higher; the nature of homelessness makes an accurate calculation almost impossible. The nature of women's homelessness is problematic too as women are able to hide their homelessness better than men through the use of family or social connections. ${ }^{40}$ Also, some women are simply loath to identify as homeless and remain invisible. ${ }^{41}$

32 On this basis, preference is expressed for the definition incorporated in the Supported Accommodation and Assistance Act 1994 (Cth): see generally Walsh, ibid, 827.

33 Ibid.

34 Australian Government Department of Families, Housing, Community Services and Indigenous Affairs, The Road Home - A National Approach to Reducing Homelessness (2008) 3.

35 Ibid.

36 Australian Bureau of Statistics, Census of Population and Housing: estimating homelessness (2011) 16; Roland Naufal and Gerry Naughtin, 'A significant minority: improving housing outcomes for older Australians' (Brotherhood of St Laurence, 2008); Australian Institute of Health and Welfare, HOU 276, Specialist homelessness services (2014).

37 Ibid.

38 Reynolds, above $\mathrm{n} 5$.

39 Ibid. According to the ABS, 5330 women over 55 were homeless. The numbers of older men, however, increased by 24 per cent in the same period.

40 Ibid.

41 Freilich, above n 17. 
Adding to this paucity of information, it is even more difficult to assess the number of older women whose are presently housed by the accommodation is precarious. This is important because without such information it is difficult to identify older people who are 'at risk' thus curtailing the opportunity to provide assistance to prevent homelessness.

\section{Causes of Housing Insecurity and Homelessness Among Older People}

\section{A Single Event or Long-Term Instability}

As with the general homeless population, homelessness amongst older Australians cannot be singularly explained. It can be triggered by a single, traumatic event or a lifetime of personal disadvantage and misfortune. ${ }^{42}$ The AIHW's 2013 report found that for the older people who sought specialist services, the cause of their homelessness could be either a relatively recent experience or as a result of long-term disadvantage or tenuous housing. ${ }^{43}$

The Commonwealth's White Paper on Homelessness released in 2008 (The Road Home: A National Approach to Reducing Homelessness) provides a summary of the main causes of homelessness in Australia. ${ }^{44}$ The report touches upon the vulnerability of certain groups, including older Australians, to experiencing homelessness:

People without support networks, skills or personal resilience, or who have limited capacity due to their age or disability, can quickly become homeless. Those with the least resources are likely to remain homeless longer. ${ }^{45}$

\section{Housing Affordability and Financial Difficulties}

Of particular pertinence to older Australians, is the issue of housing affordability and housing stress. The housing market in Australia (in particular the private rental market) remains an extremely challenging proposition for lower to middle income older people. ${ }^{46}$ The AIHW's report into specialist homelessness services seems to further articulate this point. It found an increase in the proportion of clients who sought assistance due to housing affordability, from 33 per cent to 36 per cent. ${ }^{47}$ This includes problems relating to financial difficulties, rents being too high and the 'housing crisis' ${ }^{48}$ Older clients proffered financial difficulties as the main reason for seeking assistance.

$42 \quad$ The Road Home, above n 34, 6.

43 Australian Institute of Health and Welfare, above n 36, 74.

44 The Road Home, above n 34, 7-9.

45 Ibid.

46 Housing Authority of Western Australia, Annual Report (2011-2012) 133, 162 $<\mathrm{http}$ ://www.housing.wa.gov.au/aboutus/publications/AnnualReports/Pages/ default.aspx>.

47 The Road Home, above n 34, 7.

48 Ibid. 
As with older people in general, older people experiencing homelessness are more likely to require care, assistance or medical attention. However, unlike older Australians in a stable housing environment, the ability of those experiencing homelessness to acquire the care they need is fraught. Older people experiencing homelessness are particularly vulnerable to higher rates of physical and mental illness. ${ }^{49}$ Moreover, older people may also find it more difficult to ask for assistance when faced with the prospect of homelessness or not know where to turn to for help..$^{50}$ Finally, family relationships and a sense of community, two pillars of support for older people, may be disrupted by homelessness. Older people who move from their traditional home may be forced to leave these support bases behind. ${ }^{51}$

\section{Why are Older Women at Risk of Homelessness?}

\section{The Diversity of the Cohort}

As with the general homeless population, homelessness among older women cannot be singularly explained. ${ }^{52}$ The group is diverse in age, education, location, cultural background and life circumstances. Homelessness can be triggered by a single, traumatic event or a lifetime of personal disadvantage and misfortune. Beyond the pervasive issue of domestic violence, if there is insufficient superannuation, a partner dies, a marriage breaks down later in life or something goes wrong from a health or financial perspective, many older women find themselves in difficult circumstances.

\section{Domestic Violence}

Women accounted for 52 per cent of older clients of specialist homelessness services in 2012-2013. ${ }^{53}$ This figure was proportionally lower than the overall figure (women constituted 58 per cent of all clients). ${ }^{54}$ Although women are equally as affected by housing stress and financial difficulties, they also face the additional problem of domestic and family violence, another key issue related to homelessness. ${ }^{55}$ Homelessness driven by domestic violence is often different in that the victim continually cycles in and out of homelessness. ${ }^{56}$ Research suggests that this may be because

49 Ibid, 10.

50 Deborah Batterham, 'Ageing out of place? The impact of gender and location on older Victorians in homelessness: A pilot study' Final Report (Hanover Welfare Services, 2013) 2.

51 The Road Home, above n 34, 10.

52 Diane Gibson, 'Broken down by age and gender: The Problem of Old Women Redefined' (1996) 10 Gender \& Society 433, 442; see also Freilich, above n 17.

53 Australian Institute of Health and Welfare, above n 36, 75.

54 Ibid.

55 Ibid.

56 The Road Home, above n 34, 7; indeed, even when 'at home' such women are described as 'homeless within the home': Suzie Forell et al, No home, no justice? The legal needs of homeless people in NSW - Law and Justice Foundation of NSW (2005) 5. 
the woman lacks financial independence or family support or that they accept the repentance of an abusive partner. ${ }^{57}$

According to the AIHW's report, 24 per cent of older women cited 'domestic and family violence' as the main reason they were seeking assistance. ${ }^{58}$ This compares to only 2 per cent of older men. ${ }^{59}$ Empirical evidence suggests that there are an even greater number of women who stay with family or friends rather than seeking the assistance of specialist homelessness services. ${ }^{60}$

Unfortunately, the importance of domestic violence as an issue for older women and a catalyst for homelessness is often disregarded. The issue of domestic violence is focused very much on younger women, particularly those with children. However, although statistics record rates as low, there is a considerable body of evidence in Australia and overseas suggesting that domestic violence affects a significant number of older women. The conclusion is the statistical rates are low because of a reluctance to report the incidents rather than the non-occurrence of abuse. As Imogen Blood notes:

Before the 1970s, a range of cultural and social factors - combined with the fact that domestic violence was not considered a crime - led to many women 'suffering in silence'. For many women aged 50 or over, this is still the norm. ${ }^{61}$

The 2015 extension to the National Partnership Against Homelessness $(\mathrm{NPAH})^{62}$ prioritises some groups of homelessness people, in particular women with children. Apart from concerns that highlighting certain groups over another is reminiscent of the deserving/undeserving poor dichotomy ${ }^{63}$ it needs to be borne in mind that there is no age limit for those experiencing domestic abuse. Furthermore, such older women face

$57 \quad$ Flinders University - Flinders Institute for Housing Urban and Regional Research, Women, domestic and family violence and homelessness: A Synthesis Report to (Prepared for Office of Women, South Australian Department of Families, Housing, Community Services and Indigenous Affairs, August 2008).

58 Australian Institute of Health and Welfare, above n 36, 76.

59 Ibid.

60 The Road Home, above n 34, 7.

61 Imogen Blood, 'Older Women and Domestic Violence Help the Aged', Help

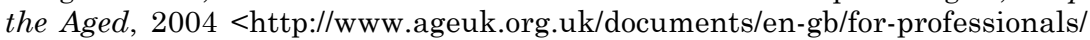
communities-and-inclusion/id2382_2_older_women_and_domestic_violence_ summary_2004_pro.pdf?dtrk=true>.

62 The Australian Government announced it would provide $\$ 230$ million for two years to 30 June 2017, with funding priority given to frontline services focusing on women and children experiencing domestic and family violence, and homeless youth under 18. The Commonwealth's commitment is conditional on State and Territory Governments matching the Commonwealth's commitment, and new reporting procedures to minimise duplication of services will be introduced: Federal Government of Australia Department of Social Services, National Partnership on Homelessness (2015) <https://www.dss.gov.au/housing-support/ programmes-services/national-partnership-agreement-on-homelessness>.

63 Kasy Chambers, 'Is Australia becoming comfortable with inequality?', Australian Broadcasting Corporation (online), 18 October 2013 <http://www.abc.net.au/ news/2013-10-15/chambers-anti-poverty-week/5022920>. 
distinct precariousness in respect of the source of abuse and alternative accommodation options. Discussions of domestic violence focus on partner to partner violence (and this, of course, occurs between older couples), however older women are increasingly vulnerable to domestic abuse from a wider circle including adult children or relatives. ${ }^{64}$ In relation to emergency accommodation they are not a priority group and/or they are limited in the time they can stay in refuges. In the absence of other alternatives, the older woman must choose between returning to the abusive environment or becoming homeless.

\section{Housing and Financial Vulnerability}

Beyond the very prescient issue of domestic violence, there have also been several recent reports into the emerging problem of older women and homelessness. These reports examine the societal trends exposing greater numbers of women to housing insecurity and potentially homelessness.

Ludo McFerran's, It Could be You, is one such report. ${ }^{65}$ McFerran argues that changes in the life expectancy of women, the lack of affordable housing, the rate of divorce and separation (and the subsequent number of women living alone) has created a potential wave of homeless, older working women. ${ }^{66}$ One particular driver is the fact that women tend to move in and out of the workforce, whilst earning less than men. ${ }^{67}$ One study found that divorced women have the lowest levels of household income, superannuation and assets. ${ }^{68}$ Another propounded that even if a woman received two-thirds of a marriage's assets at divorce, this still fails to provide housing security due to their inability to meet future housing costs. ${ }^{69}$

McFerran found that the most vulnerable women are those who are older and living alone. ${ }^{70}$ They will be poorer than men and consequently less equipped to compete in the private rental market. ${ }^{71}$ McFerran argues

64 Indeed, in the Western Australian research there were several reports of domestic abuse from adult children, particularly sons who had returned home after divorce: Freilich, above n 17.

65 Ludo McFerran, It Could be You Report: Female, Single, Older and Homeless (Report to Homelessness New South Wales, August 2010).

66 Ibid, 7-10. David de Vaus et al, The consequences of divorce for financial living standard in later life - Australian Institute of Family Studies, Research (2007) $<$ http://www.aifs.gov.au/institute/pubs/rp38/rp38.html>; Kylie Grey, 'Ageing on the edge. The new face of homelessness' Australian Broadcasting Corporation (online), 18 June 2013 <http://www.abc.net.au/radionational/programs/ backgroundbriefing/2013-08-18/4884164>.

67 Ibid, 12.

68 David de Vaus, et al, The consequences of divorce for financial living standards in later life, Research Paper, No 38 (Australian Institute of Family Studies, 2007).

69 Paul Flatau et al, What drives Australian housing careers? An examination of the role of labour market, social and economic determinants (Australian Housing and Urban Research Institute, Final Report, No 68, 2004) 37.

70 McFerran, above n 65, 15.

71 Ibid. 
that the entrenched social and economic disparity faced by women places them at risk of homelessness. ${ }^{72}$ Another study by Dr Andrea Sharam seems to echo McFerran's findings. ${ }^{73}$ Sharam similarly notes the intermittent working lives of many women (as a result of childcare responsibility) and persistent wage inequality as factors exposing women to an uncertain housing environment in retirement. ${ }^{74}$

Other research points to the growing gap between pension incomes and rents as a primary reason behind the increasing number of aged people (in particular women) seeking assistance from homelessness services. ${ }^{75}$

\section{E Particular Groups of Homeless Older Women ${ }^{76}$}

\section{Older Homeless Women with Distinctive Challenges}

The challenges of being older and homeless are magnified (if possible) in the case of seniors who are from a particular grouping who may face additional barriers.

\section{(a) Older Lesbians}

In the case of older lesbians, housing security may, of course, be undermined by circumstances affecting many older women: a lifetime of gender inequality, lower wages and lack of superannuation in retirement. ${ }^{77}$ Further, many older LGBTI people have suffered stigma and inequitable treatment throughout their lives and may be less likely to have family members engaged in their lives to provide support as they age. For example, some older lesbians may have left a heterosexual relationship. Given the societal attitudes of times past, the woman often did not fare well in divorce proceedings and property settlements. In many cases, children stayed with their father or family. ${ }^{78}$ More generally, there remains an added concern about societal attitudes that compounds vulnerability and contributes to social isolation. For example, although homelessness and LGBTI people are priority areas in the Living Longer, Living Better program, there remains a fear of discrimination from service providers and concern regarding being 'out' in an aged care setting, especially where

72 Ibid; Darab et al, above n 10.

73 Andrea Sharam, 'No Home at the End of the Road? A survey of single women over 40 years of age who do not believe they will own their housing outright at retirement' (Swinburne Institute and The Salvation Army Australia Southern Territory, 2011).

74 McFerran, above n 65, 1.

75 Hanover Welfare Services, Trish Westmore et al, Ageing in What Place? The Experience of Housing Crisis and Homelessness for Older Victorians, $2011<\mathrm{http}: / /$ www.hanover.org.au/homelessness-research-reports/ageing-in-what-place-theexperience-of-housing-crisis-and-homelessness-for-older-victorians/>.

76 Alan Morris et al, 'Older marginalised people: pathways into and out of a marginal housing situation' (2005) 11 Australian Journal of Human Rights 1, 137.

77 Freilich, above n 17, ch 14.

78 Ibid. 
the facility is administered by a religious organisation. ${ }^{79}$ As a result, some older lesbians prefer to remain in marginal circumstances, or homelessness, rather than face 'judgments' in aged care settings.

\section{(b) Older Women from CALD Backgrounds ${ }^{80}$}

Older women from culturally and linguistically diverse backgrounds also face particular difficulties when experiencing housing insecurity of homelessness. An initial barrier is the societal mindset that CALD communities 'always look after their own'. ${ }^{81}$ Sadly, this is not always the case, and for such women the difficulties associated with homelessness, including domestic violence, ${ }^{82}$ are compounded by cultural stigma, English language skills, and an inability to navigate legal and assistance options due to a lack of awareness, or in some cases an unwillingness to trust legal and community services. ${ }^{83}$ Issues may arise too with services not responding in a culturally appropriate manner, thus deterring future engagement. ${ }^{84}$

Furthermore, older women are less likely to have had the opportunity to learn English than men. ${ }^{85}$ People often revert to their first language as they age thus impacting on the ability to communicate. In some such cases, older women from CALD backgrounds have been assumed to be suffering dementia, thus sending the person down an inappropriate path with regard to rehoming. ${ }^{86}$

\section{(c) Older Aboriginal Women}

Many older Aboriginal women experience housing vulnerability through factors such as domestic violence, medical and family issues, remoteness and discrimination. ${ }^{87}$ These issues are well canvassed elsewhere. ${ }^{88}$ Of particular concern is the use of laws that, due to the societal relationship

79 Interview with Ms June Lowe (GRAI Retirement Group, Perth), September 2014.

80 Homelessness Australia, Creating a framework for ending homelessness Homelessness CALD and Migrants (2011) <http://www.homelessnessaustralia. org.au>.

81 This was a common perception noted in research for the CALD component of the Western Australian Research.

82 Flinders University, above n 57, 4.1.1, 4.1.4.

83 Security of tenure for the ageing population in Western Australia-Does current housing legislation support seniors'ongoing housing needs?; see alsoBaron, above n 12, (both Baron articles).

84 See Preventing Homelessness in Older Culturally and Linguistically Diverse (CALD) Communities Project 2015.

85 Housing for the Aged Action Group <http://www.oldertenants.org.au/news/ project-preventing-homelessness-cald-communities $>$.

86 Ibid.

87 Selina Tually et al, 'Women, Domestic and Family Violence and Homelessness: Putting Housing Back in the Equation' (2009) 22 Parity 10, 36-38.

88 See generally Coalition of Non-Government Workers Australia, Report to the UN Special Rapporteur on Housing: Women and the right to adequate housing in Australia, 2004, <http://wwda.org.au/wp-content/uploads/2013/12/ AustWomHousing04.pdf $>3.1 ; 3.8$. 
between older Aboriginal people and family, may make older Aboriginal women particularly vulnerable to the risk of homelessness. In Western Australia, for example, it is important to emphasise that social housing tenancies are subject to Div 3 of Pt V Residential Tenancies Act: Special provisions about terminating social housing tenancy agreements. Often referred to as the 'three strikes' policy, these controversial provisions have resulted in the eviction of older tenants, for example where younger family members visiting the premises cause trouble and the older person is consequently evicted. ${ }^{89}$

\section{(d) Older Women with a Disability or Illness}

Older women with a disability or illness often encounter difficulty obtaining, and maintaining, a tenancy. Many older women with a physical disability must meet additional costs such as internal and external modifications of properties, support services and health care expenses. ${ }^{90}$ Depending on the jurisdiction, the landlord may have to provide the modifications, or in others the tenant may have to arrange the work but it must be restored to its original state at the end of the tenancy. ${ }^{91}$ This creates additional expense for the tenant or the landlord and can be a factor in (usually) non-overt discrimination for landlords seeking to rent out properties. If existing modified accommodation is terminated finding new premises may be challenging.

Safety is another issue because many properties do not have appropriate access, security or fire safety features installed..$^{92}$

The impact of mental illness on homeless people, a condition that may have preceded becoming homeless, or is caused or exacerbated by the experience of homelessness, is well documented. Furthermore, there are inherent risks to the health of older homeless people including less access to health care, nutritional deficiencies, exposure and stress. ${ }^{93}$

\section{(e) Homeless Women in Rural and Regional Areas}

Homelessness in regional, and particularly rural, areas is particularly problematic. Such locations provide less available housing and, in many cases, rising rents remain problematic. ${ }^{94}$ There are limited services available to assist women who become homeless in rural and regional areas. ${ }^{95}$

$89 \quad$ Residential Tenancies Act 1987 (WA) s 75A.

90 Coalition of Non-Government Workers Australia, above n 88.

91 Ibid, 3.8.2.

92 Ibid.

93 Ibid, 3.8.

94 Ibid, 3.5-3.8: This was noted to be especially the case in in Western Australia, see generally Freilich, above n 17.

95 Suzie Forrell et al, No home, no justice? The legal needs of homeless people in NSW (Law and Justice Foundation of NSW, 2005); University of Queensland, Maree Petersen et al, 'Addressing Later Life Homelessness - Institute for Social Science Research', June 2013. For a discussion of this issue elsewhere, see Richard J First et al, 'Homelessness in Rural Areas: Causes, Patterns, and Trends Social 


\section{F Other Considerations Affecting the Housing Environment for Older People in Australia}

\section{The Changing Housing Market}

The legal rights of tenants is an increasingly important issue to this discussion because of the numbers of older people who will be renting as time goes on. ${ }^{96}$ With women tending to outlive men, more women are likely to be affected.

The Australian attitude to renting is quite different to that of other Western nations, especially Europe and many United States of America states. Australia has a high rate of home ownership, and investment in rental property is encouraged as an investment in an individual's future. Citizens are encouraged to invest in residential property through considerable taxation advantages such as negative gearing. ${ }^{97}$

In comparison, in Europe and in some United State jurisdictions, there is a much higher percentage of the population who rent throughout their lives. As Kate Shaw notes:

The resulting long leases mean tenants can consider their rented property their home and fit it out accordingly. The tenancy protections supporting this arrangement act as a disincentive to speculators, which in turn reduces demand for investment properties and therefore competition at sale. ${ }^{98}$

\section{Evolving Nations of Housing and Home}

Traditionally, the common law in relation to the occupation of a dwelling is constrained; it rarely differentiates between real property (a physical structure upon land with a capital value) and a home (described by Fox-O'Mahoney as a social, psychological, cultural and emotional phenomenon). ${ }^{99}$ Despite recognition in other academic disciplines, it

Work' (1994) 39 Social Work 1, 97-101; Paul Cloke et al, 'Interconnecting housing, homelessness and rurality: evidence from local authority homelessness officers in England and Wales' (2001) 17 Journal of Rural Studies 99, 105-106.

96 It has been predicted that the number of older people on low incomes needing affordable rental housing will reach 419,000 by 2026 . The greatest projected change is in the 85 and over age range where the number of low-income renters is estimated to increase by 194 per cent from 17,300 to 51,000: Jeff Fiedler, 'Surviving or Thriving? Older People at Risk of Homelessness in the Private Rental Market' (2014) Housing for the Aged Action Group <http://chp.org.au/ wp-content/uploads/2014/07/Fiedler.docx>.

97 'Around one in seven Australian taxpayers owns one or more investment properties, aided by generous tax concessions. Australia has one of the highest levels of household debt in the OECD due to borrowings for property purchases': Kate Shaw, 'Renting for life? Housing shift requires rethink of renters' rights' on The Conversation (7 January 2014) <https://theconversation.com/ renting-for-life-housing-shift-requires-rethink-of-renters-rights-20538>.

98 Ibid.

99 Lorna Fox-O'Mahoney, 'The Idea of Home in Law' (2005) 2 Home Cultures, 25; see also generally Lorna Fox, Conceptualising Home: Theories, Laws and Policies (Hart Publishing, 2006). 
is fair to say that real property law has been slow, even reluctant, to weigh up the importance of a secure and stable living environment for an occupant in a contest with commercial or economic considerations. It has been noted that: 'Existing legal categories and principles have been criticised for failing fully to recognise and protect home-based interests' ${ }^{100}$ with residential tenancy law being identified as one such category. ${ }^{101}$ With the exception of an unencumbered owner of land, an occupant's tenure was viewed traditionally in terms of length and nature; how long an occupant would be indulged by an owner before the law permitted the occupant to be moved on.

By considering housing as a mere commodity, its central role in the development of individuals and society is not acknowledged. It is fair to say that such attitudes are changing, albeit slowly. ${ }^{102}$ Refocusing on 'home' is a diversion from the traditional view that accommodation arrangements are merely transactions based on freedom of contract and property rights. Redefining mere occupation of property as a 'home' provides recognition of a connection between the occupant and the property and lends itself more to a human rights rather than a contractual, transactional approach.

\section{The Importance of Home and Secure Tenure to Older People}

Furthermore, the importance of security of tenure to older people should not be underestimated. Seniors have different housing requirements to younger people and families, often requiring smaller, more accessible housing that is located close to services, care and support. ${ }^{103}$ Transitions in later life are complex and 'challenge older adults to make projections of a future self and to anticipate their emotional, medical and financial needs'. ${ }^{104}$ Older people who are secure in the knowledge that they can stay in their accommodation for an extended period - or permanently - exhibit demonstrably better physical and psychological health than those in less stable accommodation. ${ }^{105}$ Insecurity in one's home environment heightens the risk of physical and psychological health implications in both the

100 Justice Kevin Bell, 'Protecting Public Housing Tenants in Australia from Forced Eviction: The Fundamental Importance of the Human Right to Adequate Housing and Home' (2012) 39 Monash University Law Review 1, 5.

101 Ibid.

102 Ibid.

103 Eileen Webb, 'Affordable Housing Is A Problem For Older Australians, Too' on The Conversation (23 December 2013) <http://theconversation.com/ affordable-housing-is-a-problem-for-older-australians-too-21555>.

104 Ibid, 4; Tam E Perry et al, 'Relocation Remembered: Perspectives on Seniors Transitions in the Living Environment' (2014) 54 Gerontologist 1, 75-81; Rosemary Hiscock et al, 'Ontological Security and Psycho-social Benefits from Home Qualitative Evidence on Issues of Tenure' (2001) 18 Housing Theory and Society 50.

105 Abir K Bekhet et al, 'Reasons for Relocation to Retirement Communities: A Qualitative Study' (2009) 31 Western Journal of Nursing Research 462. 
short and longer term, including feelings of powerlessness. ${ }^{106}$ Insecure accommodation may also impact on older people's social milieu through a reluctance to engage in their local communities or, in the event of having to relocate, the loss of existing support and friendship networks. ${ }^{107}$ The prospect of possibly having to move weighs heavily on older people, especially where there are limited options for accommodation elsewhere.

4 Economic Considerations

Finally, there are significant economic costs resultant on the heightened risk of illness and the consequences of actual or potential dislocation. Protecting tenancies for older women, and securing new accommodation promptly where an older woman has become homeless, has positive economic outcomes. Studies indicate that older women respond particularly well to appropriate interventions ${ }^{108}$ and often, if her circumstances can be 'put on the right track', problems do not recur. ${ }^{109}$ Similarly, if older women who have become homeless are quickly identified and rehoused, ${ }^{110}$ for example through community programs, again research indicates that many women do not experience homelessness again. ${ }^{11}$ Consequently, permitting older women to retain their tenancies, or rehousing them as soon as possible, will ease substantial cost on the public purse plus potentially avoid other social, health and consequent economic impacts.

\section{Recent Research on Security of Tenure for Older Western Australians, Including a Consideration of HoMelessness}

In November 2014, researchers from the Consumer Research Unit at the University of Western Australia completed a project: Security of tenure for the ageing population in Western Australia. The focus of the report was an examination of Western Australian laws and assessed whether existing legislation satisfied seniors' ongoing housing needs. One chapter considered older people experiencing homelessness, with a particular focus on older homeless women.

106 D Rutman et al, 'Anticipating Relocation: Coping Strategies And The Meaning Of Home For Older People' (1988) 7 Canadian Journal on Aging 17; Dupuis and Thorns, above n 11; Hiscock, above n 104; Frank Ozwald et al, 'Relationships Between Housing And Healthy Aging In Very Old Age' (2007) 47 Gerontologist 96.

107 Philippa Howden-Chapman et al, Housing and health in older people-Ageing in place (The University of Otago, 2010) <http://www.healthyhousing.org.nz/wp-content/ uploads/2010/01/Housing-and-health-in-older-people-aging-in-place.pdf $>$.

108 Fran Klodawsky, 'Home Spaces and Rights to the City: Thinking Social Justice for Chronically Homeless Women' (2009) 30 Urban Geography 591.

109 Peterson and Parsell, above n 2.

110 Carl I Cohen et al, 'Predictors of Becoming Redomiciled Among Older Homeless Women' (1997) 37 Gerontologist 67. See generally Natalie Waldbrook, 'Exploring opportunities for healthy aging among older persons with a history of homelessness in Toronto, Canada' (2015) 128 Social Science \& Medicine 126.

111 Peterson and Parsell, above n 2. 


\section{A Methodology}

The context of the research was the ageing Western Australian population and the housing crisis that impacted upon Western Australia during the recent mining boom. Anecdotal evidence received by COTAWA and other agencies such as ShelterWA and the Northern Suburbs Community Legal Centre's Older Peoples Rights Service suggested that older people were being particularly affected by housing stress and, in many cases, had little security of tenure. The project received ethics approval from the UWA Human Research Ethics Committee. In total, the project involved over 150 semi-structured interviews with seniors, stakeholders, relevant agencies, government, social workers and lawyers. The seniors who contributed to the project were self-selecting. Advertisements were placed in local and State newspapers and distributed through the networks of COTAWA and other relevant agencies. Information was distributed through community legal centres, community organisations, drop-in centres and hostels. The experiences of individual respondents resulted in a series of case studies under each of the relevant accommodation types.

The ensuing report was comprised of 17 chapters, each of which dealt with a different form of accommodation and considered how the law may impact in a particular way on older people. The report also considered issues that could undermine seniors' security of tenure such as 'assets for care' arrangements and misuse of enduring powers of attorney.

\section{B Summary of Findings in Relation to Older Homeless Women}

In summary, research undertaken for the homelessness chapter confirmed findings discussed earlier in this article about the increasing number of older homeless women. Some interviewees had been in and out of homelessness for some time, primarily as a result of domestic violence and/or financial difficulties, while others had become homeless for the first time. In relation to the first group, several expressed the view that, now they were older, they could not 'go on like this' and preferred the uncertainty of a refuge or actual homelessness to the domestic situation. All had serious financial issues that prevented them from 'moving on', for example, two women interviewed returned to their home within days of the interview due to lack of alternative pathways. Some still had responsibilities for adult children, in one case an intellectually disabled adult child, or grandchildren.

The second group contained some women who experienced domestic violence but predominantly were in this predicament because of financial issues forcing them to the brink or into homelessness. The financial misfortune was from a number of sources including the failure of arrangements with family, financial abuse by family members, being 'priced out' of the private rental market, being evicted from a property due to disagreements with the landlord or manager, or the inability to make rental payments due to illness or other unforeseen expenses. 
Both groups were comprised of women from all socio-economic backgrounds and levels of education. Despite this, all were constrained financially and were experiencing high degrees of stress. Most had no understanding of the legal system and had no desire to engage as there were 'too many other worries'. The women who had been experiencing domestic violence for some time had some understanding of relevant procedures but were, for the most part, disillusioned with the process. All were experiencing health issues including depression, chronic illness and in one case a potentially terminal illness. All were concerned about the lack of affordable housing and the vagaries of marginal accommodation including the attitudes of landlords and fear of eviction or increasing rent.

The research team were concerned by the lack of awareness as to the availability of services and the reluctance to engage with the legal system where appropriate. Most had found out about services by 'word of mouth' with few accessing electronic platforms. Several had obtained assistance because friends or associates had pursued the matter on their behalf or, after exhausting other avenues, some women contacted government agencies and were referred on. Two of the women were assisted after presenting at a public hospital.

The distrust of legal avenues was of concern. Those who were experiencing housing vulnerability were of the view that the law had no relevance to their situation. In short, those still in housing regarded the situation as one where the landlord 'held all the cards' and that there was no money to pay lawyers anyway. There was some, but not significant awareness, of community legal centres. Also, many of the women were of the view that such centres focused on 'families, children, that sort of thing' and that they would be outside the 'ambit' for assistance. Those who were homeless or who moved between marginal housing and homelessness saw the law as more of a threat than an asset. Those who had experienced domestic violence doubted the law's effectiveness 'for anything' whereas others were fearful of enforcement due to experiences with police or rangers, for example, while sleeping in cars or, less commonly, being in public places.

To summarise, the Western Australian research concluded that in the case of vulnerable tenants - including older women - pursuing a legal solution was rarely considered an option. Part 3 of this article will consider ways in which the law - and lawyers - can play a more significant role in alleviating housing insecurity and homelessness.

\section{Can Property Law Play a Role in Alleviating Housing Insecurity and Homelessness for Older WOMEN? ${ }^{112}$}

As discussed in Part 1, older women experiencing housing vulnerability and homelessness are unable to afford rental payments and/or may have

112 Forrell et al, above n 95. 
to leave accommodation because a term has expired, the situation is for various reasons untenable, the property has been sold or some other accommodation arrangement has ceased. Furthermore, the existing law does not pay heed to the discrete vulnerabilities of older female tenants/ occupants. ${ }^{113}$ In our view, property law can play a constructive role in alleviating housing vulnerability and homelessness generally, including in relation to older women, by:

(a) reconfiguring traditional approaches to landlord and tenant law to take into account Australia's human rights obligations, the changing nature of the housing market and the social, economic and health benefits of safeguarding security of tenure; and

(b) pursuing appropriate law reform.

\section{A Reconfiguring Traditional Approaches to Landlord and Tenant Law}

Property laws regulating accommodation include legislation regulating public and private rental, residential parks, caravan parks and, in most jurisdictions, boarding and lodging establishments. ${ }^{114}$ Such laws seek to balance the rights of landlords/owners and tenants/occupants but, in fact, do little to protect security of tenure, nor does such legislation effectively prevent significant rental increases or impose minimum standards on rental properties. Furthermore, 'no cause' termination of tenancies are authorised. ${ }^{15}$ Such legislation rarely pays heed to vulnerabilities such as age. Furthermore, in some cases there is no legislation at all governing particular accommodation arrangements. For example, despite the increasing prevalence of such agreements, there is little effective regulation of family accommodation (assets for care) arrangements where older people, most commonly older women, invest in a child's property in exchange for care as the older person ages. ${ }^{116}$

Traditionally, property law has seen its role as one of safeguarding existing property rights and ensuring contractual and commercial certainty. This approach, however, is arguably out of step with Australia's international obligations with regard to inter alia the right to adequate housing and ignores the realities of the evolving Australian housing market.

113 Teresa Somes et al, 'What role for the law in regulating older peoples' property and financial arrangements with adult children? The case of family accommodation arrangements' in Barry Kozak and Ralph Reubner (eds), International Perspectives on the Rights of Older Persons (Vandeplas Publishing, 2015).

114 For the purposes of this article, Western Australian legislation will be utilised.

115 See generally D Pippen, 'Security of tenure: Tenancy law reform' (2009) 94 Australian Law Reform Commission Reform Journal 20.

116 See generally Somes et al, above n 113. 
1 Australia's International Obligations With Regard to Housing, Ageing and Women

In Australia, the Commonwealth Parliament may enter into international treaties pursuant to $\mathrm{s} 51$ (xxxix) of the Constitution. ${ }^{117}$ It is all very well, however, to refer to these international obligations, but implementation and adherence is another matter entirely. Australia has adopted a dualist theory of the relationship between international and national law. ${ }^{118}$ Ratification does not result in the rights and obligations being automatically included in Australian law. ${ }^{119}$ To do so, the provisions have to be enacted as part of domestic law, whether by Commonwealth or State statute. ${ }^{120}$ Victoria and the Australian Capital Territory have introduced Charters based on the International Covenant on Civil and Political Rights. The charters are relevant to this discussion as the provisions would seem to provide some safeguard in relation to housing, at least in the case of public housing tenancies in those jurisdictions. ${ }^{121}$ The International conventions can, of course, be used as inter alia as a tool of statutory interpretation where a provision in ambiguous $\mathrm{s}^{122}$ or in the development of the common law. ${ }^{123}$

\section{The Right to Adequate Housing}

Article 25(1) of the Universal Declaration of Human Rights provides for a right to an adequate standard of living for individuals and their families including food, clothing, housing and medical care. ${ }^{124}$ Security of tenure, in the context of adequate housing, is considered in two international

117 The Commonwealth may make laws regarding matters incidental to the execution of any power vested by this Constitution in the Parliament or in either House thereof, or in the Government of the Commonwealth, or in the Federal Judicature, or in any department or officer of the Commonwealth.

118 Justice Michael Kirby, 'Domestic implementation of international human rights norms' (Speech delivered at Conference on implementing international human rights, Australian National University, 6 December 1997) referring to R Higgins, Problems and Process - International Law and How We Use It (Clarendon, Oxford, 1994) 204 <http://www.hcourt.gov.au/assets/publications/speeches/ formerjustices/kirbyj/kirbyj_inthrts.htm\#_ftn2>.

119 Koowarta $v$ Bjelke-Petersen (1982) 153 CLR 168, 224-225 (Mason J); 193 (Gibbs CJ).

120 Ibid.

121 Bell, above n 100, 5.

122 Minister for Immigration and Ethnic Affairs $v$ Teoh (1995) 183 CLR 273, 291.

123 Ibid: '[I]nternational human rights law may have a powerful bearing on the development of the common law, the interpretation and application of statutes and the Australian Constitution, the process of administrative decision-making (and the review of administrative decision-making), and the development and application of social justice policies', Philip Lynch, 'From "Cause" to "Solution" Using the Law to Respond to Homelessness' (2003) 28(3) Alternative Law Journal $127,130$.

124 United Nations, Universal Declaration of Human Rights (1948) < http://www. un.org/en/documents/udhr/>. 
covenants, the International Covenant on Civil and Political Rights (ICCPR) and the International Covenant on Economic, Social and Cultural Rights (ICESCR). Article 11(1) ICESCR states:

1. The States Parties to the present Covenant recognize the right of everyone to an adequate standard of living for himself and his family, including adequate food, clothing and housing, and to the continuous improvement of living conditions. ${ }^{125}$

This Article is clarified by General Comment No 4 that notes:

The human right to adequate housing, which is derived from the right to an adequate standard of living, is of central importance for the enjoyment of all economic, social and cultural rights.

The concept of adequacy under the Covenant will, of course, vary depending on the differing circumstances of Member States. It is possible, however, to identify several factors that can be used as touchstones. Paragraph 8 of General Comment No 4 identifies seven factors from which an assessment of 'adequate housing' can be made, being: legal security of tenure; availability of services, materials, facilities and infrastructure; affordability; habitability; accessibility; location; and cultural adequacy. It is therefore instructive to examine whether existing laws regulating accommodation arrangements reflect the aspirations encapsulated in these factors. For illustration, case examples involving older women from the Western Australian research will be utilised.

\section{(a) Does Existing Legislation Reflect the Right to Adequate Housing? ${ }^{126}$}

(i) Legal Security of Tenure ${ }^{127}$

There is little legal security of tenure in the private rental market. Long term residential leases are rare and short notice periods are the norm. Most fixed term residential leases are for terms of only 612 months. Nothing in the legislation states the terms must be so limited, it has

125 Note also that Art 17 ICCPR includes the right to be free from arbitrary or unlawful interference with privacy, family and home, and to be protected by law against such interference: United Nations Human Rights Office of the High Commissioner for Human Rights, International Covenant on Civil and Political Rights (23 March 1976) <http://www.ohchr.org/en/professionalinterest/pages/ ccpr.aspx>.

126 To date there is no binding international instrument focusing on the rights of older people, and certainly not older homeless women, as a discrete group. Australia has, however, ratified seven international human rights treaties of which some have relevance to this discussion. Several instruments refer to a right to adequate housing and forbid discrimination in relation to inter alia age, gender, disability and ethnicity. Furthermore, homelessness impacts upon several fundamental rights and freedoms including in relation to health, discrimination, privacy, and security of the person.

127 Security of tenure: housing is not adequate if its occupants do not have a degree of tenure security which guarantees legal protection against forced evictions, harassment and other threats. 
simply become common practice. ${ }^{128}$ Furthermore, in most cases, after the initial fixed term agreements revert to periodic tenancies, thus reducing the requisite period of notice. In the Western Australian research, most older women in housing stress had been renting for a considerable time, usually in the same home, but on rolling periodic leases.

Security of tenure is a concern for older people who invest in manufactured homes but rent the land on which the home is placed. Such accommodation is promoted widely as a lower cost retirement option and is popular with older women because of the sense of community fostered within some parks and the proximity to services. Although "lifestyle villages' offer lengthy periods of tenure, many manufactured home parks provide little security of tenure, and, in the absence of a fixed term, the notice period can be as little as 60 days. ${ }^{129}$ Furthermore, manufactured homes are expensive to move, especially for those on low or fixed income and there may not be another available or affordable site. For example, in Western Australia many parks have been sold for redevelopment were sold for redevelopment. Several respondents to the Western Australian research found they were unable to relocate the home and, even where they could do so, the alternative park was a significant distance from the original location thus undermining networks and access to familiar services. In some cases, the home had to be sold (invariably at a significant loss) and the older person had to seek accommodation elsewhere.

In Western Australia, private and public tenants, some residents residing in residential and caravan parks, ${ }^{130}$ and boarders and lodgers are subject to no-cause evictions. Protection from forced eviction is pivotal to the human right to adequate housing under the ICCPR and the ICESCR. In most jurisdictions a residential tenancy agreement can be terminated for breach of a term of the agreement, if the owner has sold the property or without cause ${ }^{131}$ Critically, there is no compulsion to refer to legitimate cause for the eviction or the hardship that it may cause. Several commentators are of the view that the no cause provisions offend the international prohibition on forced eviction. ${ }^{132}$ Although evictions are justifiable in appropriate circumstances, such as damage and the continuous non-payment of rent, the eviction should not take place where that would render the tenant homeless. ${ }^{133}$

128 Although we spoke to women who had been in a property for a long time, it was always a short term arrangement.

129 This is the case in Western Australia. Notice requirements vary from State to State.

130 It is important that a distinction is drawn between occupants in Lifestyle Villages who have lengthy periods of tenure and other residential parks where tenure and notice periods can be as little as 60 days.

131 Residential Tenancies Act 1987 (WA) s 64.

132 Bell, above n 100.

133 General comment No 7 (para 17) also emphasises that forced evictions should not result in individuals being made homeless. OHCHR/UN Habitat, The Right to Adequate Housing Fact Sheet 21 (Office of the United Nations High Commissioner for Human Rights, 2009) 27-28. 
Recent amendments to Western Australian legislation have been likened to forced eviction. The Residential Tenancies Act 1987 (WA) was amended to incorporate a 'three strikes' policy; controversial provisions where, after three complaints about a public housing tenancy, the tenant can be evicted. The policy has resulted in the eviction of - predominantly - older Aboriginal tenants. ${ }^{134}$ The typical scenario is where younger family members visiting the premises cause disruption and the older person is consequently evicted. ${ }^{135}$ The policy has seen several older Aboriginal women made homeless and requiring alternative accommodation. ${ }^{136}$

In comparison, in several European jurisdictions, rental periods are lengthy, there are strict limitations upon termination and, in some cases, additional protections for older tenants. ${ }^{137}$ And, unlike Australia where 76 per cent of private rentals are owned by 'mum and dad' investors, ${ }^{138}$ in Western Europe there are large landholding institutions that treat their housing assets as long term secure investments that provide a steady return. ${ }^{139}$

In France the minimum term of a lease in most cases is three years where the landlord is an individual and six years where the landlord is a corporation. Unless there is a valid notice to vacate, leases are renewed by operation of law for the same period and on the same conditions. ${ }^{140}$ There are caps on rental for lengthy time periods, safeguards against excessive rents and landlords must show just cause to terminate a lease.

134 Residential Tenancies Act 1987 (WA) s 75A; 'Termination of social housing tenancy agreement due to objectionable behaviour', applies solely to public housing tenants. This provision has been labelled as the 'three strikes policy'. Under the section, the Department of Housing (DOH) may apply to the court to terminate a tenancy on the basis that the tenant has:

- Caused or permitted the premises to be used for illegal purposes;

- Caused or permitted a nuisance to occur on the premises; or

- Interfered or permitted an interference to neighbours.

Whether the impugned activity or behaviour has been recurring is a factor that the court will consider in making a determination. The court has a wide discretion to make orders. The ambit of $\mathrm{s} 75 \mathrm{~A}$ is further expanded in the $\mathrm{DOH}$ manual. In essence, a tenant must not cause a nuisance or permit a guest to cause a nuisance. Consequently, a tenant is responsible for not only their own behaviour, but for the behaviour of others on their premises with their permission.

135 See the discussion of Schaefer v Department of Housing (No 2) [2012] WASCA 229.

136 For a recent topical example, see Steve Grant, 'Waiting for the knock on the door', Fremantle Herald, 23 May 2015, 1.

137 Webb, above n 103.

138 Ibid. See also Julie Power, 'More people renting for longer as hopes of ownership fade', Sydney Morning Herald, 20 June 2014.

139 See generally Natalie Wharton, Security of tenure: Conformity of Australia's states and territories residential tenancy laws with the human right to housing (undated) $<$ http://www.iut.nu/Australia/Sudi_caseWharton.pdf $>$.

140 Republique Francaise, LOI, Article 10 - No 89-462 (6 July 1989). See the discussion in Adrian Bradbrook, 'Residential tenancy law - lessons from France' (1997) 5 Australian Property Law Journal 107. 
Interestingly, older renters again receive additional protections with Bradbrook noting:

Article 15III of the 1989 Law provides special conditions for aged persons in the case of a notice to vacate. The article states that where the landlord serves a notice to vacate, the notice will be ineffective where the tenant is aged over 70 years and has an annual income less than one and one half times the amount of the minimum salary unless the landlord offers the tenant housing corresponding to the tenant's needs within a prescribed geographic range. ${ }^{141}$

The exception to this provision is where the landlord himself is aged over 60 years, or where his or her annual income is less than one and one half times the amount of the minimum salary. ${ }^{142}$

In Germany, the notice requirements vary according to how long the tenant has lived there: three months is the minimum notice for someone who has lived in the property for less than five years. Six months' notice is required for a tenancy between five and eight years, nine months for longer than eight years. In the case of elderly long term tenants, a landlord has to make a very strong case for their eviction and is required to pay compensation and/or assist with their relocation. Tenants remain in possession even when the property is sold. ${ }^{143}$

While such legislation is sourced in a very different residential environment, it is important to at least consider these approaches. More Australians, including older Australians, are renting and it is anticipated that the number of residential renters will continue to rise. ${ }^{144}$

\section{(ii) Affordability ${ }^{145}$}

Affordability is one of the main factors causing housing vulnerability with rental payments, in some cases, taking up between 50-80 per cent of pensions. ${ }^{146}$ Residential tenancy legislation contains provisions purporting

141 Ibid.

142 Ibid.

143 For an excellent overview of the German law, and Western European tenancy laws generally see Nathalie Wharton and Lucy Cradduck, 'A comparison of security of tenure in Queensland and Western Europe' (2011) 37(2) Monash University Law Review 16, 30. See also Magnus Hammar, 'Naming and Shaming' [2007] (January) Global Tenant International Union of Tenants' Quarterly Magazine 7, 7.

144 Wendy Stone et al, Long term private rental in a changing Australian private rental sector (Australian Housing and Urban Research Institute, Final Report, No 209, 2013) 42.

145 Affordability: housing is not adequate if its cost threatens or compromises the occupants' enjoyment of other human rights. The issues discussed under this heading are also relevant to another element: Availability of services, materials, facilities and infrastructure: housing is not adequate if its occupants do not have safe drinking water, adequate sanitation, energy for cooking, heating, lighting, food storage or refuse disposal.

146 Housing for the Aged Action Group (HAAG). The now de-funded National Housing Supply Council reported in 2010 that 35 per cent of renters over 65 years of age are paying more than 30 per cent of their income in rent (this includes 
to limit 'excessive' rent increases but this is calculated on a market based formula rather than the impact or hardship on the tenant. Also, there is a general lack of awareness of these provisions and, even if advised, tenants reported a reluctance question the rent increase because of fear of eviction. ${ }^{147}$ Similar concerns arise for tenants in residential and caravan parks and boarding and lodging establishments. For example, in the Western Australian research, several older women interviewed were experiencing housing stress due to rising rents. Most had been long term renters but, with gentrification of traditionally cheaper suburbs and the influx of mining personnel in the past decade, the rents became unaffordable. Even with legislative provisions seeking to avoid excessive increases, the reality was that market rents were rising quickly and significantly. They were justifiable on the basis of the market but there is no opportunity to consider the resultant hardship. High rents can threaten or compromise the occupants' enjoyment of other human rights. The research revealed many cases of older women needing to forego food, heating and medical care in order to meet rising rental. Inevitably, in some cases, homelessness ensued. In comparison, in Germany, which is reflective of general tenant protection in Europe, rent increases are capped at 20 per cent every three years and landlords who overcharge can be fined. ${ }^{148}$

\section{(iii) Habitability ${ }^{149}$}

With the exception of Tasmania, residential tenancy legislation does not stipulate minimum standards for private rental housing. ${ }^{150}$ This means that many of the health and safety factors that are essential to the wellbeing of older people cannot be guaranteed. Indeed, there is no requirement to provide homes with adequate heating or insulation. In Western Australia there are safeguards for security measures, but this is not the case in several other States. Despite repair and maintenance obligations on landlords, the Western Australian research found many older women who were living in sub-standard premises because they believed that if they sought repairs their rent may be increased or they may be asked to leave. The research indicated too that some landlords are reluctant to rent to older people as there was a perception that older people are demanding and may require structural modifications to the property.

the addition of rent assistance to their income). The average rent paid by Home at Last clients is usually in the range of 50 per cent to 80 per cent of income as they reach the tipping point of affordability <http://www.oldertenants.org.au/ home_at_last>.

147 Freilich, above n 17.

148 Wharton, above n 139.

149 Habitability: housing is not adequate if it does not guarantee physical safety or provide adequate space, as well as protection against the cold, damp, heat, rain, wind, other threats to health and structural hazards.

150 Part 3B (ss 36I-36P) of the Residential Tenancies Act 1997 (Tas): As of June 2015, all homes to be rented will have to have facilities including a flushing toilet, running water, heating and ventilation. 
The Western Australian research considered conditions in boarding and lodging establishments for older women. For the most part, such accommodation has been primarily occupied by men and the most premises remain more suitable for occupation by men. Many older women who access boarding and lodging establishments report lack of privacy and feelings of insecurity in such circumstances.

\section{(iv) Accessibility ${ }^{151}$}

Many rental properties are not adaptable to cope with the ageing process. Landlords are not required to install modifications and, despite residential tenancy and discrimination legislation, older people do not tend to ask for fear of eviction. Also, in circumstances where improvements are made, there may be a cost at the end of the lease to have them removed, often at a significant cost to the older person to restore the premises. Some people reported having to leave accommodation because it was too difficult to access and occupy due to age-related conditions. ${ }^{152}$ This latter issue is of particular concern to older people with disabilities. ${ }^{153}$

\section{(v) Cultural Adequacy ${ }^{154}$}

Relevant legislation does not address issues of cultural adequacy and research in Western Australia, and elsewhere indicates CALD seniors (including Aboriginal seniors) are among the most vulnerable renters. Indeed, special programs are being rolled out to raise awareness of homelessness services and to overcome cultural resistance within private and public housing markets. ${ }^{155}$

In the case of Aboriginal seniors, the three strikes policy is a most concerning development. It is suggested that the policy ignores the realities of Aboriginal families and the obligations on older people to take in family.

Although not strictly an issue of cultural adequacy, it should be noted that there can be a lack of patience amongst landlords regarding issues that commonly affect older people. For example, under the RTA the tenant is responsible for keeping the premises in a reasonable state of cleanliness ${ }^{156}$ and must not intentionally or negligently cause or permit damage

151 Accessibility: housing is not adequate if the specific needs of disadvantaged and marginalised groups are not taken into account.

152 Freilich, above n 17, ch 4.

153 Ibid, ch 13.

154 Cultural adequacy: housing is not adequate if it does not respect and take into account the expression of cultural identity.

155 For example, the Home at Last program and the program focused older CALD seniors by the Housing Actions Group for the Aged.

156 Residential Tenancies Act 1987 (WA) s 38(1)(a). Premises includes chattels provided with the premises (whether under the agreement or not) for use by the tenant: s 38(2). 
to the premises. ${ }^{157}$ Several case studies involved eviction and attempted eviction of older people pursuant to this provision due to behaviours such as hoarding. Indeed, litigation involving the Western Australian Department of Housing found that considerable clutter, even though the premises were not unhygienic, contravened the legislation. ${ }^{158}$

Our concern with such decisions is that relatively harmless behaviour, sometimes simply part of ageing, could be used to trigger termination. Hoarding (of property and animals) is a growing issue and has been recognised as a complex behavioural disorder. ${ }^{159}$ It is acknowledged that those suffering Alzheimer's symptoms can be prone to hoarding. ${ }^{160}$

This discussion has demonstrated that legislation addressing public and private rentals, and more marginal forms of accommodation often utilised by older people, do not - in several significant respects - satisfy the elements of the right to adequate housing. Unfortunately, this finding coalesces with criticism by the Special Rapporteur regarding Australia's lack of compliance in safeguarding the right to adequate housing. ${ }^{161}$ The 2006 report concluded that the Australian housing system was beset by considerable inadequacies, especially in relation to vulnerable people. Areas of concern included widespread unaffordability creating a very large demand for affordable accommodation and public housing, lack of secure tenure for tenants in both public and private rental accommodation and discrimination in accessing private housing, particularly rental accommodation.

In relation to the adequacy of the residential tenancies legislation it was stated:

The Special Rapporteur also notes the weakness in Australian legislation, its implementation and monitoring in regard to the right to adequate housing. Legislation gives little regard to the rights of tenants and legislations. Tenancy laws or the anti-discrimination acts are difficult to use due to the pressure of the market (fear of retaliation) and the existence of "black-list" databases. ${ }^{162}$

It was noted too that no laws exist in Australia that comply with international human rights standards involving forced eviction. ${ }^{163}$ In summary, it was recommended that Australia adopt an integrated human rights approach to relevant tenancies legislation that utilised the elements of adequate housing.

157 Residential Tenancies Act 1987 (WA) s 38(1).

158 Schaffer $v$ Clerk of the Magistrates Court Fremantle [2011] WASCA 223; Schaefer $v$ Housing Authority [2011] WASCA 222; Schaeffer $v$ Department of Housing (No 2) [2012] WASCA 229.

159 Los Angeles Foundation on Ageing, Elderly Tenant Hoarding Program <http:// www.givelafa.org/programs/programs.php\#>.

160 Ibid.

161 Miloon Kothari, United Nations Special Rapporteur on adequate housing: mission to Australia - Preliminary Observations $2006<$ http://apo.org.au/research/unitednations-special-rapporteur-adequate-housing-mission-australia-premlinary>.

162 Ibid.

163 Ibid. 


\section{(b) United Nations Principles for Older Persons}

At present, there is no international convention on the rights of older persons. ${ }^{164}$ Nevertheless, there are several existing international human rights instruments that impact upon the rights and freedoms of older persons, including the right to housing and shelter. ${ }^{165}$ In 1991, the United Nations General Assembly adopted the United Nations Principles for Older Persons. ${ }^{166}$ Although the resolution is not binding on governments, nations are encouraged to take heed of the contents of the resolution when formulating government policy. Three principles are of particular interest to this article:

- Independence: Older persons should have access to food, water, shelter, clothing, health care, work and other income-generating opportunities, education, training and live in safe environments;

- Care: Older persons should have access to social and legal services and to health care so that they can maintain an optimum level of physical, mental and emotional well-being. This should include full respect for dignity, beliefs, needs and privacy; and

- Dignity: Older persons should be able to live in dignity and security, be free of exploitation including physical or mental and be treated fairly regardless of age, gender and racial or ethnic background.

\section{(c) The Convention on the Elimination of All Forms of Discrimination against Women}

Furthermore, several provisions of the Convention on the Elimination of All Forms of Discrimination against Women (CEDAW) are relevant to a discussion of older homeless women, particularly Art 13 that deals with economic and social rights and echoes the sentiments in the International Declaration, the ICCPR and the ICESCR with reference to safe, secure and affordable housing. Of course, several other instruments have relevance to homelessness but, for the purposes of this article, the focus is primarily on matters directly affecting housing options for older women. ${ }^{167}$

3 Some Possible Avenues

From our discussion of the legislation it can be seen that the criteria for adequate housing stipulated by the UN either is not incorporated or can be

164 Most recently, the General Assembly of the United Nations passed a resolution in December 2010 which resulted in the establishment of an Open Ended Working Group on Ageing. In August 2014, the Chicago Declaration, a draft convention was settled. Unfortunately, there appears to be little appetite to take the matter forward.

165 For example, the Universal Declaration of Human Rights (UDHR), International Covenant on Civil and Political Rights (ICCPR), International Covenant on Economic, Social and Cultural Rights (ICESCR), Covenant on the Rights of Persons with Disabilities (CRPD) and the UN Principles for Older Persons.

166 See Resolution 46/91.

167 Jacqueline Cole, 'Homelessness and Human Rights: Regarding and responding to homelessness as a human rights violation' (2003) 4 Melbourne Journal of International Law 141. 
easily avoided in practice. The next consideration is whether Australia's ratification of the relevant international instruments could allow us to enhance relevant accommodation laws?

In Minister for Immigration and Ethnic Affairs $v$ Teoh, ${ }^{168}$ the High Court developed the 'doctrine of legitimate expectation' whereby a treaty establishing individual rights creates a legitimate expectation that the Commonwealth and its agencies will abide by these rights. The court may refer to international instruments in the case of statutory ambiguity or to develop the common law. ${ }^{169}$ The stumbling block is, however, that the RTA, and like legislation, is not ambiguous. The legislation, including the most troubling provisions such as no cause termination, are clear on their face and it is unlikely that there is any ambiguity such as to permit the use of the international conventions to interpret the provisions.

Another possibility is to adopt the recommendation of the Special Rapporteur and adopt a human rights approach to legislation that utilises the elements of adequate housing. Although this is theoretically possible, sadly, we doubt that any government would have the political motivation or will to take this approach at this stage. Similar comments can be made regarding the likelihood of a Bill of Rights or the recognition of a Right to Housing. ${ }^{170}$

Even if there is no ambiguity such that the legislation cannot be interpreted through international conventions, human rights laws may still assist. Part IV ICCPR and Pt IV ICESCR stipulate that the Commonwealth government must periodic reports regarding Australia's observance and realisation of the rights in the Covenants. Monitoring bodies have been established for both the ICCPR and the ICESCR that encourage non-governmental organisations to provide information in relation to compliance with international human rights obligations. Such oral or written materials are said to "supplement or "shadow" the Australian Government's report'. ${ }^{171}$ Indeed, Lynch et al note:

Homeless persons' advocates should also consider initiating individual complaints to the HRC under the Optional Protocol where the civil or political rights of a homeless person have been violated and that person has exhausted all effective and available local remedies seeking redress for the violation. ${ }^{172}$

Finally, another avenue may be recourse to the Universal Periodic Review (UPR); a review of a nation's human rights record. Before the UPR the country under review and the Office of the High Commissioner of Human Rights provided reports. UN Member States may consult the country's representatives about its human rights record and make recommendations.

\footnotetext{
168 (1995) 183 CLR 273, 291.

169 Ibid.

170 This discussion is beyond the scope of this article. For an excellent recent discussion on this issue see Walsh, above $\mathrm{n} 31$.

171 Ibid.

172 See Lynch, above n 123.
} 


\section{B Possibilities for Law Reform}

Law reform could take the form of legislation directly addressing homelessness, incorporation of international obligations into Australian law and/or review or amendment of existing legislation.

\section{Homelessness Legislation}

The Commonwealth Homelessness Bill 2013 aspired to increase 'recognition and awareness of persons who are, or are at risk of, experiencing homelessness ${ }^{173}$ and was part of a broader reform process to reduce homelessness. ${ }^{174}$

The legislation was effectively a general overview of what constitutes homelessness in Australia, the causes, and possible policies aimed at amending the situation. It must be said that there was considerable, and justifiable, criticism that the legislation was weak and would require significant amendment to enhance its provisions to ensure meaningful operation. ${ }^{175}$ Indeed, s 14 encapsulated the lack of substance in the Bill by stating that the 'Act does not create or give rise to rights or obligations'. Furthermore, the Bill did not provide for a legislative right to housing. ${ }^{176}$

It is suggested that there should be an effort to reinvigorate efforts to enact national legislation targeted at alleviating homelessness. Such legislation would entrench homelessness as a consideration within the legislative framework and lend support to Australia's international commitment to a right to adequate housing. Symbolic legislation has its place and articulating concerns regarding homelessness in legislation ensures such matters are considered by governments. ${ }^{177}$ It could also spur legislatures into considering the reasons for homelessness and the economic and social desirability of keeping people housed when considering legislative change. Finally, the existence of such legislation may encourage the law to adopt of a human rights framework in its response to matters involving homelessness. ${ }^{178}$

173 Homelessness Bill 2013 (Cth) cl 3. In 2008 the Commonwealth Government released its White Paper: The Road Home: A National Approach to Reducing Homelessness. The centrepiece of the legislation was the introduction of a Commonwealth Homelessness Act that would 'underpin the national response to homelessness, setting standards to deliver the best quality services possible'.

174 Explanatory Memorandum, Homelessness Bill 2013 (Cth) 1. The aims of the reform process included halving the homeless rate by 2020 and providing accommodation for all 'rough sleepers'. The Bill was introduced into the Commonwealth Parliament in 2012, was read a first and second time in the House of Representatives and a first time in the Senate. The Bill lapsed in late 2013.

175 See, for example, the response from ShelterWA; see too no connection to the existing framework of law, policy and intergovernmental agreements that govern homelessness funding and service delivery. Joint submission by Homeless Law and the Council to Homeless Persons on the Homelessness Bill 2012 (Cth).

176 Explanatory Memorandum, Homelessness Bill 2013 (Cth) 1.

177 See again the discussion by Walsh, above $\mathrm{n} 31$.

178 Ibid. 
Residential Tenancy and Other Legislation Relevant to Accommodation

The RTA and like legislation could be amended to incorporate at least some of the provisions regarding adequate housing. Additional provisions could be incorporated to ensure additional protections for vulnerable people such as older tenants. The legislation could provide for minimum periods of tenure of several years or an open ended agreement that cannot be terminated on a whim. ${ }^{179}$ Considerations such as hardship in relation to rental increases and termination of the arrangement could be incorporated. Minimum requirements for the standard of properties should be incorporated into the existing legislation together with provisions that deter discrimination.

Wharton notes that nearly all Western European legislatures ${ }^{180}$ only permit landlords to terminate a contract where there is a legitimate reason: either serious breach of the tenancy by the tenant or the landlords requirement to use ${ }^{181}$ or occupy the property. Additionally, there are limitations on even a legitimate termination if the departure would cause hardship to the tenant, for example difficulty finding a new dwelling. It is suggested that such provisions could be incorporated into tenancy legislation without undue restraints on landlords. Similarly, provisions providing additional protections for elderly tenants, such as those in France, could be utilised.

Law reform is required in a specific area where many older people are at risk of manipulation: 'assets for care' arrangements where an older person shares property with adult children in exchange for a home as that person ages. The legal position surrounding such arrangements is uncertain; there is no legislation directly applicable and, in the event of a dispute, reference must be made to the common law and equity. The State, Territory, and Commonwealth Parliaments should cooperate to develop and implement legislation regulating formalities, content, and use of assets for care arrangements and provide for adequate remedies in the event of the agreement's failure. The remedies awarded to older people where family accommodation arrangements fail are often insufficient for them to start again and obtain new accommodation. ${ }^{182}$

\section{Other Laws of Relevance to Retirement Income}

In relation to other issues that may alleviate housing stress for older women, Art 11(1)(d) relates to equal pay, an issue vital to the gender gap in income throughout women's lives and its consequent impact in retirement. The Article has relevance to the issue of superannuation

179 For example, as is the case of the Queensland manufactured homes legislation.

180 Wharton refers to legislation in Austria, Belgium, Denmark, France, Germany, Ireland, Italy, Luxemburg, Norway, Portugal, Spain, Sweden, Switzerland, the Netherlands and the United Kingdom. See Wharton, above n 139.

181 Ibid. This extends to renovation, alteration or sale.

182 Somes et al, above n 113. 
and the numbers of women in unpaid or lower paid work. ${ }^{183}$ Reference is also made to ending violence against women, an issue relevant to women prior to becoming homeless (as a reason for leaving) and during periods of homelessness (due to vulnerability while homeless).

A perplexing problem for older women experiencing housing stress is financial vulnerability caused by job insecurity, income inequality, and resultant impacts on retirement income. It is suggested that reform is urgently needed to workplace, taxation and superannuation laws. For example, closer attention should be paid to age discrimination in the workforce. Furthermore, it has been suggested that the Commonwealth Government should consider modifying the superannuation system, so that superannuation payments are gendered and included in paid parental leave payments, so that women do not miss out on contributions throughout their lives.

In recent years there has been considerable discussion about age discrimination in the workplace, wage inequality, the lower wages in 'women's work' and the resulting impact on superannuation, but little translation into law reform. In our view, taking heed of these issues and dealing with them through appropriate law reform now will mitigate further escalation of the numbers of older women experiencing inadequate income in retirement. Importantly, it is not enough to argue that superannuation in younger generations will fill the void; the situation involving wages, time out of the workforce to care for children or ageing parents and superannuation accumulation will, without government will and resultant law reform, remain the same.

\section{Conclusions}

This article has examined the rising number of older people experiencing housing vulnerability and homelessness and has focused on older women in particular. Sadly, there is no conspicuous panacea, nor will the enactment of laws, of itself, adequately address the issue. Furthermore, remedial measures are complex and are not the preserve of any one discipline. ${ }^{184}$

This does not mean, however, that lawyers should not reconsider the existing approaches to housing vulnerability. Australian landlord and tenant laws have exhibited a commercial bias with accommodation regarded more as a commodity to be exploited than another person's home. As such, the legal framework rarely takes into account the individual circumstances of people in housing stress nor considers the potential impact that a lack of security of tenure can cause, particularly in old age. Such an approach seems inappropriate with the likelihood that less

183 Susan Bisom-Rapp et al, 'It's complicated: Age, gender and lifetime discrimination against working women - The United States and UK as examples' (2014) 22 Elder Law Journal 1.

184 Clearly, several of the approaches discussed extend to people experiencing homelessness at any age, but our focus on older women seeks to highlight the particular vulnerabilities of this often invisible cohort. 
Australians will become - or remain - home owners. As noted above, such an approach is also at odds with several of Australia's international obligations, in particular the right to adequate housing.

This article commenced with a discussion of the housing vulnerability experienced by a rising number of older women in Australia. It then moved to consider whether existing laws addressing a rage of accommodation types satisfied the elements of the right to adequate housing and raised the possibility of courts referring to these principles in the course of interpreting such legislation. The article then looked at the potential for law reform, not only in relation to property laws but also in relation to laws that could alleviate housing vulnerability through ensuring greater financial freedom for women at retirement. From this discussion, six proposals can be identified. It should be noted that other possibilities have been mooted elsewhere that but are beyond the scope of this article. ${ }^{185}$

1. More research should be directed towards housing vulnerability issues experienced by older women. We are not saying that any one 'group' of homeless people are more deserving of attention than others. Our point is that this particular group are often 'invisible' and in some circumstances find themselves excluded from services and assistance. ${ }^{186}$

2. The courts and legislature should pay more heed to Australia's international conventions, in particular the right to adequate housing, in relation to the drafting and interpretation of legislation.

3. Legislation addressing homelessness should be reintroduced. As discussed above, even symbolic legislation has a place to draw attention to the issue and underscore the issue's status as a concern of government.

4. Consideration should be given to introducing provisions such as those utilised in Europe, for example lengthier fixed term, limitations on termination, hardship provisions and protections for vulnerable, including ageing, tenants.

5. Law reform is required as a matter of urgency to regulate family accommodation (assets for care) arrangements. Failure of such arrangements can severely undermine older people's, particularly older women's, housing security.

6. Greater focus should be directed at the gender-pay gap, shortfalls in lifelong income and superannuation and the impact of women's

185 Eric Post, 'Combating homelessness through law and disorder: Social movement tactics to achieve the fundamental right to adequate housing' (Undated) <http:// www.academia.edu/827823/COMBATING_HOMELESSNESS_THROUGH_ LAW_AND_DISORDER_SOCIAL_MOVEMENT_TACTICS_TO_ACHIEVE_ THE_FUNDAMENTAL_RIGHT_TO_ADEQUATE_HOUSING >; Michael Diamond, 'The Meaning and Nature of Property: Home ownership and Shared Equity in the Context of Poverty' (2009) 29 St Louis University Pubic Law Review 85.

186 Carol Vale et al, 'More than a roof over my head: Dignity and community for older homeless women in Australia' (2014) 27 Parity 8, 12. 
contributions as carers on their acquisition of property and retirement income.

In summary, greater reference to Australia's human rights obligations in the interpretation of housing legislation could see tenancies safeguarded, thus avoiding many cases of homelessness. We acknowledge that this would necessitate a rethinking in the law's approach to property transactions, however we are of the view that this shift can be justified due to the changing nature of the Australian housing market, perceptions of housing and impact of stable housing on economic, social and health outcomes. 